\title{
Influence of Phosphorus in Starter Fertilizer on the Establishment of Tall Fescue
}

\author{
Bohan Liu and Peter J. Landschoot ${ }^{1}$ \\ Department of Plant Science, Pennsylvania State University, University \\ Park, PA 16802
}

Additional index words. Mehlich-3 P, turfgrass renovation, turf establishment, Festuca arundinacea Schreb., monoammonium phosphate

\begin{abstract}
Phosphorus (P)-containing starter fertilizers are often recommended for establishing new turf, regardless of $P$ levels indicated by the soil test. However, few field studies have been conducted to determine the effects of $P$ in starter fertilizer on the rate of turf establishment. The primary objective of this study was to determine if $P$ in starter fertilizer enhances tall fescue groundcover and growth during establishment on silt loam soil. This 2-year field study was conducted on silt loam soil tilled with a rototiller or core-aerated and vertically sliced. Mehlich-3 $P$ levels ranged from 38 to $270 \mathrm{mg} \cdot \mathrm{kg}^{-1}$. Experiments were conducted during late summer and fall, and all tests were seeded with 'Bullseye' tall fescue (Festuca arundinacea Schreb.). Treatments included 49 and 73.5 $\mathrm{kg} \cdot \mathrm{ha}^{-1}$ of nitrogen $(\mathrm{N})$ without $P, 49 \mathrm{~kg} \cdot \mathrm{ha}^{-1}$ of $\mathrm{N}$ plus three different rates of $P(24.5,49$, and $73.5 \mathrm{~kg} \cdot \mathrm{ha}^{-1}$ ), and a nonfertilized control. Comparisons between groups that received treatment with $49 \mathrm{~kg} \cdot \mathrm{ha}^{-1}$ of $\mathrm{N}$ without $P$ and treatments with $49 \mathrm{~kg} \cdot \mathrm{ha}^{-1} \mathrm{~N}$ with $P$ revealed few significant groundcover responses to the addition of $P$. Of 12 groundcover assessments performed during four experiments, contrasts revealed only one instance of a higher percentage of groundcover in response to the addition of $P$. This occurred during an experiment having a pretreatment Mehlich-3 P level of $38 \mathrm{mg} \cdot \mathrm{kg}^{-1}$. Comparisons indicated greater clipping yields in response to the addition of $P$ in one of the four experiments. This occurred in soil that was core-aerated and sliced with an initial Mehlich-3 P level of 66 $\mathrm{mg} \cdot \mathrm{kg}^{-1}$. In most cases, Mehlich-3 $\mathbf{P}$ levels at the end of each experiment increased as the $P$ application rates increased. The only instance in which comparisons between treatment with $49 \mathrm{~kg} \cdot \mathrm{ha}^{-1} \mathrm{~N}$ without $\mathrm{P}$ and treatments with $49 \mathrm{~kg} \cdot \mathrm{ha}^{-1} \mathrm{~N}$ with $\mathrm{P}$ demonstrated a significant leaf tissue response to $P$ during the experiment with soil that was core-aerated and sliced with a pretreatment Mehlich-3 P level of $66 \mathrm{mg} \cdot \mathrm{kg}^{-1}$. When individual treatments were compared, the $73.5 \mathrm{~kg} \cdot \mathrm{ha}^{-1} \mathrm{~N}$ treatment without $\mathrm{P}$ produced similar or higher groundcover and clipping yields than all other treatments during all four experiments. This study revealed few groundcover and variable tall fescue clipping yield responses to $P$ additions when applied at rates used for starter fertilizer applications on silt loam soil during late summer and fall. Groundcover and growth responses due to $P$ in starter fertilizers do not appear to be solely related to soil test $P$ levels, and other factors such as the method of establishment (tilling soil vs. core-aerating and slicing the soil surface), environmental conditions, and the $\mathbf{N}$ content of soil may be involved.
\end{abstract}

Impaired water quality in the Chesapeake Bay and other surface waters due to excess phosphorus $(\mathrm{P})$ is receiving scrutiny from state and federal environmental regulatory agencies. Although agricultural operations

Received for publication 10 Sept. 2018. Accepted for publication 24 Oct. 2018 .

This work was supported by the USDA National Institute of Food and Agriculture, Hatch project 1006804.

Any opinions, findings, conclusions, or recommendations expressed in this publication are those of the authors and do not necessarily reflect the view of the National Institute of Food and Agriculture or the USDA. Some financial support for this research was provided by the Pennsylvania Turfgrass Council.

We gratefully acknowledge Timothy Lulis for providing technical assistance, Zenon Lis (Burlingham Seeds, LLC) for supplying tall fescue seed, and John Pope (The Andersons, Inc.) for providing monoammonium phosphate.

${ }^{1}$ Corresponding author. E-mail: pj11@psu.edu. are considered the largest single source of $\mathrm{P}$ loading of the Chesapeake Bay (USEPA, 2010), fertilizer practices in urban and suburban areas are receiving more attention as a source of P contamination (Milesi et al., 2005; Schueler, 2010; Soldat and Petrovic, 2008). In response to environmental concerns and $\mathrm{P}$ restrictions, many fertilizer companies have reduced or eliminated $\mathrm{P}$ in synthetic turfgrass maintenance fertilizers; however, $\mathrm{P}$ is still present in organic and starter fertilizers.

Starter fertilizers typically contain higher amounts of $\mathrm{P}$ than maintenance fertilizers, and they are applied to the soil surface at the time of seeding to hasten the establishment of turfgrasses and improve root development. The use of starter fertilizers containing $\mathrm{P}$ is frequently recommended for turfgrass establishment by university extension publications and by public and private soil test laboratories and consulting agencies. Often, recommendations for applying P-containing starter fertilizers at the time of establishment are made regardless of the nutrient status of soil (Hardebeck et al., 2005). However, data from cropping systems and turfgrass research suggest that, at certain sites with high $\mathrm{P}$ according to soil test results, high-P starter fertilizers may not provide significant improvements in the crop yield or rate of turf establishment compared with $\mathrm{N}$ fertilizer with low amounts of $\mathrm{P}$, fertilizer with no $\mathrm{P}$, and, occasionally, fertilizer with no $\mathrm{N}$ and no $\mathrm{P}$ (Reicher et al., 2000; Roth et al., 2006; Vetsch and Randall, 2000).

Improved establishment of cool-season turfgrasses following incorporation of high rates of $\mathrm{P}$ fertilizer into soils containing low amounts of $\mathrm{P}$ has been well-documented. Christians et al. (1981) reported an increase in groundcover of kentucky bluegrass ( $P$ oa pratensis L.) resulting from $540 \mathrm{~kg} \cdot \mathrm{ha}^{-1} \mathrm{P}$ applied to soil containing low P. Turner and Waddington (1983) found that the application of $P$ in the range of 160 to $400 \mathrm{~kg} \cdot \mathrm{ha}^{-1}$ is beneficial for promoting rapid turfgrass establishment (groundcover, yield, and quality) in silt loam soil with low P

Although the aforementioned studies showed improved establishment of coolseason grasses following $\mathrm{P}$ applications in soils containing low $\mathrm{P}$ levels, responses to $\mathrm{P}$ fertilizer in intermediate-P and high-P soils (>50 mg. $\mathrm{kg}^{-1}$ Mehlich-3 P) are not as clear. Carroll et al. (2005) conducted greenhouse studies to determine the growth response of tall fescue seedlings to the addition of $\mathrm{P}$ in eight soils with high $\mathrm{P}$ according to soil test results (52 to $277 \mathrm{mg} \cdot \mathrm{kg}^{-1}$ Mehlich-3 P) under different temperatures. Under warm temperatures, the growth of tall fescue increased linearly with increasing $\mathrm{P}$ rates, but no response to $\mathrm{P}$ additions occurred in soils with $\geq 163 \mathrm{mg} \cdot \mathrm{kg}^{-1}$ Mehlich-3 P. The response of tall fescue to $\mathrm{P}$ additions under cool temperatures showed increased seedling growth after $\mathrm{P}$ fertilizer applications to soils with $\geq 163 \mathrm{mg} \cdot \mathrm{kg}^{-1}$ Mehlich-3 P.

In a separate greenhouse study, Carroll et al. (2005) examined growth responses to $\mathrm{P}$ additions in soils ranging from 52 to 97 $\mathrm{mg} \cdot \mathrm{kg}^{-1}$ Mehlich-3 P under warm temperatures and found positive responses in all soils except for one with $97 \mathrm{mg} \cdot \mathrm{kg}^{-1}$. The authors concluded that under warm temperatures and adequate moisture, the addition of $\mathrm{P}$ at seeding will have little impact on tall fescue seedling growth in soils with $>97 \mathrm{mg} \cdot \mathrm{kg}^{-1}$ Mehlich-3 P, but that seedling growth may increase with $\mathrm{P}$ additions in soils with $>97$ $\mathrm{mg} \cdot \mathrm{kg}^{-1}$ Mehlich-3 $\mathrm{P}$ under adverse growing conditions.

Hamel and Heckman (2006) conducted extensive greenhouse studies and two field experiments using soils from New Jersey to determine critical levels of $\mathrm{P}$ according to soil test results for the rapid establishment of kentucky bluegrass, perennial ryegrass (Lolium perenne L.), and tall fescue. The authors reported that critical $\mathrm{P}$ levels vary among species, with kentucky bluegrass having higher $P$ requirements than tall fescue and perennial ryegrass. Critical soil test $\mathrm{P}$ values 
estimated from tall fescue and perennial ryegrass based on relative clipping yields were $170 \mathrm{mg} \cdot \mathrm{kg}^{-1}$ for Mehlich-1, $233 \mathrm{mg} \cdot \mathrm{kg}^{-1}$ for Bray-1, and $280 \mathrm{mg} \cdot \mathrm{kg}^{-1}$ for Mehlich-3.

Two field seedling establishment experiments were conducted by Hamel and Heckman (2006) using the same soils as those in one of their greenhouse experiments. Findings from one experiment site showed a positive linear turf density response to the $\mathrm{P}$ rate for kentucky bluegrass, but not for perennial ryegrass. A significant treatment response and linear response for tall fescue density were found for only one of five rating dates. Results from the other site showed that kentucky bluegrass and perennial ryegrass were not responsive to $\mathrm{P}$ additions, but that tall fescue responded to increased $\mathrm{P}$ rates with increased turf density on two of six rating dates. The authors stated that these results represent an example of how the use of critical levels identified in greenhouse studies may have incorrectly predicted the need for $\mathrm{P}$ fertilization in the field.

A field study conducted by Reicher et al. (2000) investigated the influence of surface applications of $\mathrm{N}$ and $\mathrm{P}$ at typical starter fertilizer rates on kentucky bluegrass established on different seeding dates during late summer/fall and late winter/spring. The authors reported significant effects of the seeding date on establishment, but no effects were caused by the fertilizer treatments. Reicher et al. (2000) attributed the lack of response to fertilizer treatments to high fertility levels of the silt loam soil.

Hardebeck et al. (2005) conducted a 2year field study to determine the effects of varying $\mathrm{P}$ and potassium $(\mathrm{K})$ rates on the establishment of tall fescue. Tall fescue was seeded on three dates at two locations with different soil $\mathrm{P}$ and $\mathrm{K}$ levels. At the low $\mathrm{P}$ and $\mathrm{K}$ fertility location, the application of 98 $\mathrm{kg} \cdot \mathrm{ha}^{-1} \mathrm{P}$ increased spring turf cover by $21 \%$ at plots that received no $\mathrm{P}$ during the September seeding date treatment. However, no yield or groundcover differences due to $\mathrm{P}$ were observed at the high-P site. The authors concluded that incorporating $\mathrm{P}$ at seeding should continue to be a recommended practice because it improves establishment in soils with medium to low P levels.

Previously cited reports demonstrated variability in the responses of cool-season grasses to $\mathrm{P}$ additions when established in soils with medium to high $P$ levels according to a soil test. Some of the differences among studies may be due to grass species and cultivar, soil type, how the study was conducted (greenhouse vs. field), soil temperatures, and possibly other factors. Because public concern regarding $\mathrm{P}$ losses and water contamination has called into question standard fertilizer practices, including routine application of $\mathrm{P}$ in starter fertilizers, additional research is warranted to determine the influence of $\mathrm{P}$ on the establishment of coolseason turfgrasses.

The primary objectives of this study were to determine if $\mathrm{P}$ in starter fertilizer applied at the time of establishment influences groundcover and foliar growth of newly established tall fescue in silt loam soil with a range of $\mathrm{P}$ during late summer and fall and to determine changes in foliar tissue $\mathrm{N}$ and $\mathrm{P}$ and the $\mathrm{P}$ results of a soil test in response to $\mathrm{P}$ fertilizer applied at rates typical of starter fertilizer applications to turf. Tall fescue was of particular interest in this study because of its increasing popularity as turfgrass, and because its nutritional requirements have not been extensively studied in the northern area of the Chesapeake Bay watershed.

\section{Materials and Methods}

Four field experiments involving the application of $\mathrm{N}$ fertilizer, with and without $\mathrm{P}$, during turf establishment were conducted at the Joseph Valentine Turfgrass Research Center (JVTRC) and the Landscape Management Research Center (LMRC) in University Park, PA, during 2011 and 2012. Two of the experiments were conducted on soils that were tilled with a rototiller, and two were performed on surfaces that were core-aerated and vertically sliced instead. The soil at the JVTRC and LMRC sites is a Hagerstown silt loam (fine, mesic Typic Hapludalfs).

Fertilizer $N$ and $P$ experiments on tilled soil. Two experiments examining the influence of $\mathrm{N}$ and $\mathrm{P}$ fertilizer on tall fescue establishment were conducted on tilled silt loam soil at the LMRC site during 2011 and 2012. Before starting the 2011 experiment, the site consisted of a 10-year-old stand of perennial ryegrass that had not been fertilized for 3 years. The 2012 experiment at LMRC was located immediately adjacent to the 2011 site; it consisted of a 15-year-old stand of kentucky bluegrass containing $2.5 \mathrm{~cm}$ of thatch and broadleaf weeds that had not been fertilized for at least 4 years.

On 25 July 2011 and 30 July 2012, glyphosate (Round-up Pro; Monsanto Co., St. Louis, MO) was applied at $5.4 \mathrm{~kg} \cdot \mathrm{ha}^{-1}$ to kill existing turf and weeds at the 2011 and 2012 LMRC sites, respectively. Soil was rototilled to a depth of 10 to $15 \mathrm{~cm}$ on 22 Aug. 2011 (2011 experiment) and on 21 Aug. 2012 (2012 experiment). The tilled soil was manually graded with a grading rake and firmed using a drag mat on 15 Sept. 2011 and on 22 Aug. 2012.

Soil samples $7.6 \mathrm{~cm}$ in depth were collected from the 2011 and 2012 LMRC experiment sites following tilling and grading and were analyzed for chemical properties at the $\mathrm{Ag}$ ricultural Analytical Services Laboratory (AASL) in University Park, PA, using methods reported by Wolf and Beegle (1995). Soil test results from the 2011 experiment site showed $38 \mathrm{mg} \cdot \mathrm{kg}^{-1}$ Mehlich-3 P, $186 \mathrm{mg} \cdot \mathrm{kg}^{-1}$ Mehlich$3 \mathrm{~K}$, a cation exchange capacity of 14.6 $\mathrm{cmol}_{\mathrm{c}} \cdot \mathrm{kg}^{-1}$, and a $\mathrm{pH}$ of 6.7 . Results from the 2012 site indicated $53 \mathrm{mg} \cdot \mathrm{kg}^{-1}$ Mehlich-3 P, $206 \mathrm{mg} \cdot \mathrm{kg}^{-1}$ Mehlich-3 K, a cation exchange capacity of $13.3 \mathrm{cmol}_{\mathrm{c}} \cdot \mathrm{kg}^{-1}$, and a $\mathrm{pH}$ of 6.5 .

Fertilizer treatments for the 2011 and 2012 experiments on tilled soil included 49 $\mathrm{kg} \cdot \mathrm{ha}^{-1} \mathrm{~N}, 73.5 \mathrm{~kg} \cdot \mathrm{ha}^{-1} \mathrm{~N}, 49 \mathrm{~kg} \cdot \mathrm{ha}^{-1} \mathrm{~N}+24.5$ $\mathrm{kg} \cdot \mathrm{ha}^{-1} \mathrm{P}, 49 \mathrm{~kg} \cdot \mathrm{ha}^{-1} \mathrm{~N}+49 \mathrm{~kg} \cdot \mathrm{ha}^{-1} \mathrm{P}, 49 \mathrm{~kg} \cdot \mathrm{ha}^{-1}$
$\mathrm{N}+73.5 \mathrm{~kg} \cdot \mathrm{ha}^{-1} \mathrm{P}$, and a nonfertilized control. The $\mathrm{N}$ source was ammonium sulfate $(21-0-0)$ (Helena Chemical Co., Warriors Mark, PA), and the $\mathrm{P}$ source was monoammonium phosphate (MAP) (11-52-0) (The Andersons, Maumee, $\mathrm{OH})$. The amounts of ammonium sulfate used in treatments were adjusted to account for the addition of $\mathrm{N}$ from MAP. Individual plots were seeded with 'Bullseye' tall fescue at $29.5 \mathrm{~g} \cdot \mathrm{m}^{-2}$ (Burlingham Seeds LLC, Rickreall, OR). Fertilizer treatments and seed were applied to the soil surface separately using shaker jars and lightly raked into the soil to a depth of $\approx 1$ cm on 18 Sept. 2011 and 25 Aug. 2012. Plots were covered with DeWitt Seed Guard Fabric (Gemplers, Madison, WI) to prevent seed movement and were removed at the first sign of seedling emergence. Plots for both experiments were $1.2 \times 1.8 \mathrm{~m}$, and the experimental design was a randomized complete block design with three replications.

During 2011 and 2012, $\approx 0.38 \mathrm{~cm}$ of irrigation was applied two times per day beginning immediately after seeding and until tall fescue seedlings emerged and covers were removed from plots. Following emergence, irrigation was applied at $0.38 \mathrm{~cm}$ once per day unless a rain event provided enough precipitation to keep the soil surface moist; in which case, no irrigation was applied. Air temperature data indicated warm daily high temperatures $\left(\geq 14{ }^{\circ} \mathrm{C}\right)$ during the first 2 weeks of the 2011 test period and the first 4 weeks of the 2012 test period for the tilled soil experiments (Fig. 1). This was followed by variable but generally cooler temperatures for the remainder of both test periods. The mean high temperatures for the 2011 test period (18 Sept. to 4 Nov.) and 2012 test period (25 Aug. to $20 \mathrm{Nov}$.) were 16 and $17{ }^{\circ} \mathrm{C}$, respectively; however, the mean low temperatures for the 2011 and 2012 test periods were both $8{ }^{\circ} \mathrm{C}$. Removal of covers, digital groundcover assessments, and clipping harvests were the only source of traffic on the plots during the experiments.

The percentage of living groundcover was assessed visually and using digital photography during the experiments. Only visual groundcover ratings were determined early during each test on 22 Oct. for the 2011 experiment and 27 Sept. for the 2012 experiment, when seedlings were susceptible to the potential damaging effects of placing digital assessment equipment on the plots. Visual and digital assessments of groundcover on treatment plots were made after the final clipping harvest at the end of each experiment (4 Nov. for the 2011 experiment and 20 Nov. for the 2012 experiment). Digital images were obtained using a camera (Nikon Coolpix P6000 with the setting at 8 megapixelfine; Nikon, Tokyo, Japan) mounted in an aluminum box that prevented ambient light from influencing images. The image resolution was $3264 \times 2448$, and the jpeg compression ratio was 1:4. Digital images were $50.8 \mathrm{~cm} \times$ $61.0 \mathrm{~cm}\left(0.3 \mathrm{~m}^{2}\right)$; they were analyzed using SigmaScan Pro 5.0 with the Turf Analysis macro developed by Karcher and Richardson (2005). 

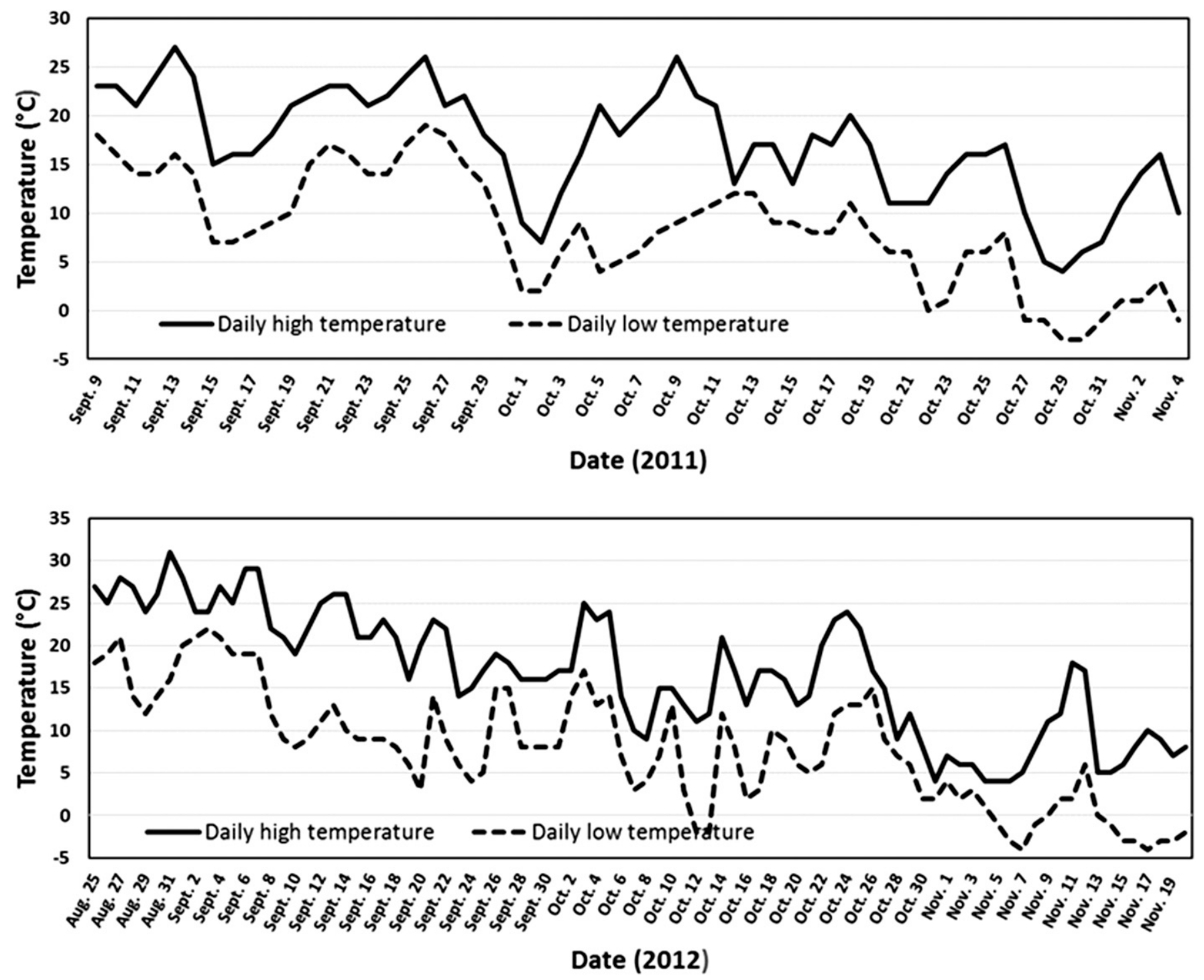

Fig. 1. Maximum and minimum daily air temperatures recorded in University Park, PA, during the 2011 and 2012 starter fertilizer experiments.

Table 1. Means of visual and digital estimates of tall fescue groundcover for treatments with $49 \mathrm{~kg} \cdot \mathrm{ha}^{-1} \mathrm{~N}$ during 2011 and 2012 following seeding on tilled Hagerstown silt loam soil. Plots were seeded on 18 Sept. for the 2011 experiment and on 25 Aug. for the 2012 experiment. Tests were conducted at the Landscape Management Research Center in University Park, PA.

\begin{tabular}{|c|c|c|c|c|c|c|}
\hline \multirow{2}{*}{ Treatment $\left(\mathrm{kg} \cdot \mathrm{ha}^{-1}\right)$} & \multicolumn{3}{|c|}{2011 Expt. on tilled soil } & \multicolumn{3}{|c|}{2012 Expt. on tilled soil } \\
\hline & Visual groundcover & Visual groundcover & Digital groundcover & Visual groundcover & Visual groundcover & Digital groundcover \\
\hline $49 \mathrm{~N}+0 \mathrm{P}$ & 53 & 78 & 73 & 93 & 97 & 95 \\
\hline $49 \mathrm{~N}+49 \mathrm{P}$ & 68 & 83 & 73 & 93 & 96 & 97 \\
\hline $49 \mathrm{~N}+73.5 \mathrm{P}$ & 65 & 84 & 82 & 94 & 95 & 97 \\
\hline \multicolumn{7}{|c|}{ Significance probability } \\
\hline Contrast $^{2}$ & $0.003^{* *}$ & $0.17^{\mathrm{NS}}$ & $0.10^{\mathrm{NS}}$ & $0.85^{\mathrm{NS}}$ & $0.41 \mathrm{NS}$ & $0.27^{\mathrm{NS}}$ \\
\hline \multicolumn{7}{|c|}{ Linear coefficient of determination } \\
\hline$R^{2}$ & 0.22 & 0.14 & 0.04 & 0.02 & 0.004 & 0.08 \\
\hline
\end{tabular}

${ }^{\mathrm{z}}$ Comparisons between treatment with $\mathrm{N}$ but no $\mathrm{P}$ and treatments with $\mathrm{N}$ and $\mathrm{P}$ were used for trend analyses.

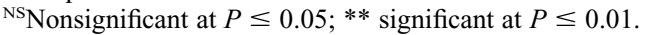

In addition to the percentage of living groundcover, the response of tall fescue to fertilizer treatments was observed in clipping yields and leaf tissue $\mathrm{N}$ and $\mathrm{P}$ concentrations. Clippings were collected from the entire $2.2-\mathrm{m}^{2}$ plots at a $6.1-\mathrm{cm}$ mowing height using a Honda HRR217HZA rotary mower

HortScience Vol. 53(12) December 2018 equipped with a $53-\mathrm{cm}$ deck and a grass catch bag (American Honda Motor Co., Torrance, CA). Clippings were collected once on 4 Nov. at the conclusion of the 2011 experiment. Due to the prolific foliar growth during the 2012 experiment, separate harvests were performed on 24 Sept., 11 Oct., and 20 Nov.
2012. Clipping weight data were combined at the end of the 2012 experiment to provide total clipping weights for each treatment.

Clippings from each plot were placed in paper bags and weighed immediately. Following weighing, clippings were placed into a forced-air dryer for $2-3 \mathrm{~d}$, then ground in a 

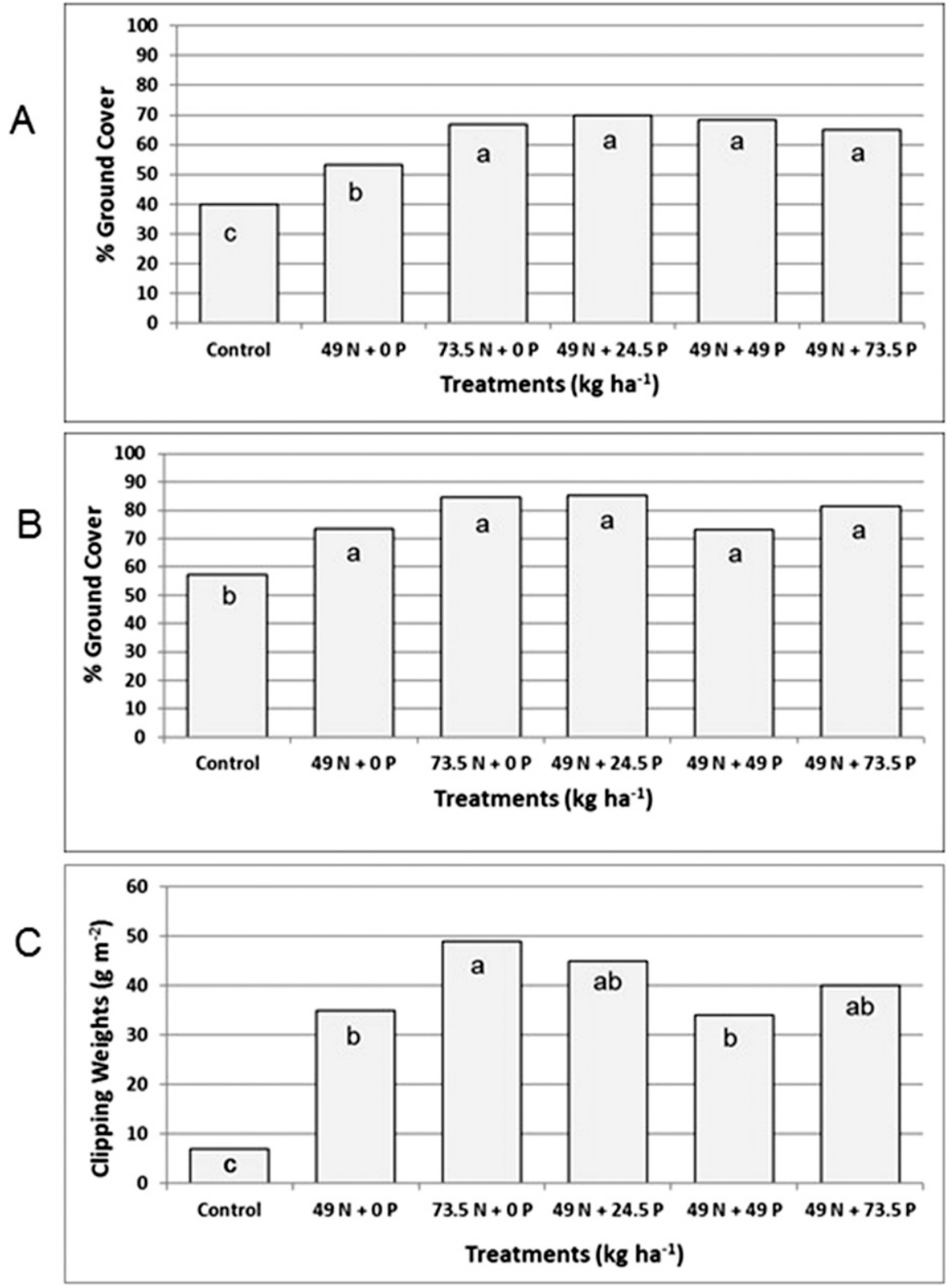

Fig. 2. Percentage of turf groundcover assessed visually on 22 Oct. (A), percentage of groundcover assessed digitally on 4 Nov. (B), and clipping weights on 4 Nov. (C) from the 2011 tilled soil N and P fertilizer experiment at the Landscape Management Research Center in University Park, PA.

Wiley mill with a 2-mm screen, and analyzed for $\mathrm{N}$ by the combustion method in an Elementar Vario Max N/C Analyzer (Horneck and Miller, 1998) and for $\mathrm{P}$ by nitric acid and hydrogen peroxide digestion and inductively coupled plasma emission spectroscopy at AASL (Huang and Schulte, 1985).

Soil samples to a depth of $7.6 \mathrm{~cm}$ were collected from each plot during the 2011 and 2012 LMRC experiments at their conclusions on 8 Nov. 2011 and 30 Nov. 2012. All soil samples were analyzed at AASL. The P was extracted from 2.5 -g soil samples using the Mehlich-3 extractant and a procedure developed by Mehlich (1984). The P levels were determined via inductively coupled plasma emission spectroscopy (Huang and Schulte, 1985).

Fertilizer $N$ and $P$ experiments using soil that was core-aerated and sliced. Two field death of the turf and weeds, the areas were core-aerated with a Toro ProCore 648 aerator (The Toro Co., Minneapolis, MN) equipped with $2.5-\mathrm{cm}$-diameter tines on $3.75-\mathrm{cm}$ centers. Cores were allowed to dry on the surface before being broken apart by vertical slicing later the same day. Experiment areas were vertically sliced in four directions with a slit seeder to a depth of 0.6 to $1.3 \mathrm{~cm}$ using a Turfco TriWave-60 seeding/slicing unit (Turfco Manufacturing, Inc., Blaine, MN).

Fertilizer treatments and $\mathrm{N}$ and $\mathrm{P}$ sources included in the 2011 and 2012 experiments using core-aerated and sliced soil were identical to those described for the 2011 and 2012 tilled soil experiments. The plot size for both experiments was $1.2 \times 1.8 \mathrm{~m}$, and the experimental designs were randomized complete block designs with three treatment replicates.

Experiment areas were both seeded with 'Bullseye' tall fescue at $29.5 \mathrm{~g} \cdot \mathrm{m}^{-2}$, and fertilizer treatments were applied on 9 Sept. 2011 and 14 Sept. 2012. After seeding, plots were covered with DeWitt Seed Guard Fabric to prevent seed movement. Covers were removed at the first indication of seedling emergence. The irrigation program for the 2011 and 2012 core-aerated and sliced soil experiments was identical to that described for the tilled soil experiments. Air temperature data indicated that daily high temperatures were $\geq 14{ }^{\circ} \mathrm{C}$ during the first 3 weeks of the 2011 and 2012 test periods for the nontilled soil experiments (Fig. 1). The mean high temperatures for the 2011 experiment period (9 Sept. to 3 Nov.) and 2012 experiment period (14 Sept. to 5 Nov.) were 17 and $16{ }^{\circ} \mathrm{C}$, respectively; however, the mean low temperatures for the 2011 and 2012 experiment periods were $9{ }^{\circ} \mathrm{C}$ for both. No traffic except for the removal of covers and data collection events occurred on treatment plots during the experiments.

Immediately before commencement of the 2011 and 2012 experiments, soil samples to a depth of $7.6 \mathrm{~cm}$ were collected from the experiment site. Samples were analyzed for chemical properties at AASL. Soil test results from the 2011 experiment indicated 270 $\mathrm{mg} \cdot \mathrm{kg}^{-1}$ Mehlich-3 P, $290 \mathrm{mg} \cdot \mathrm{kg}^{-1}$ Mehlich-3 $\mathrm{K}$, a cation exchange capacity of $15 \mathrm{cmol}_{\mathrm{c}} \cdot \mathrm{kg}^{-1}$, and a $\mathrm{pH}$ of 7.0. Soil test results from the 2012 experiment showed $66 \mathrm{mg} \cdot \mathrm{kg}^{-1}$ Mehlich-3 P, $163 \mathrm{mg} \cdot \mathrm{kg}^{-1}$ Mehlich-3 K, a cation exchange capacity of $8.5 \mathrm{cmol}_{\mathrm{c}} \cdot \mathrm{kg}^{-1}$, and a $\mathrm{pH}$ of 7.0 .

Evaluation criteria were identical to those described for the 2011 and 2012 tilled soil experiments and included groundcover estimates (visual and scanned digital photographs), clipping weights, $\mathrm{N}$ and $\mathrm{P}$ concentrations in turf leaf tissue, and Mehlich-3 $\mathrm{P}$ from soil samples. Percent groundcover was assessed visually on 10 Oct. and 3 Nov. for the 2011 experiment, and on 18 Oct. and 5 Nov. for the 2012 experiment. Digital images of treatment plots were obtained after the clipping harvest at the end of each experiment ( 3 Nov. for the 2011 experiment and 5 Nov. for the 2012 experiment). Clippings were collected once on 3 Nov. for the 2011 experiment and once on 5 Nov. for the 2012 
A
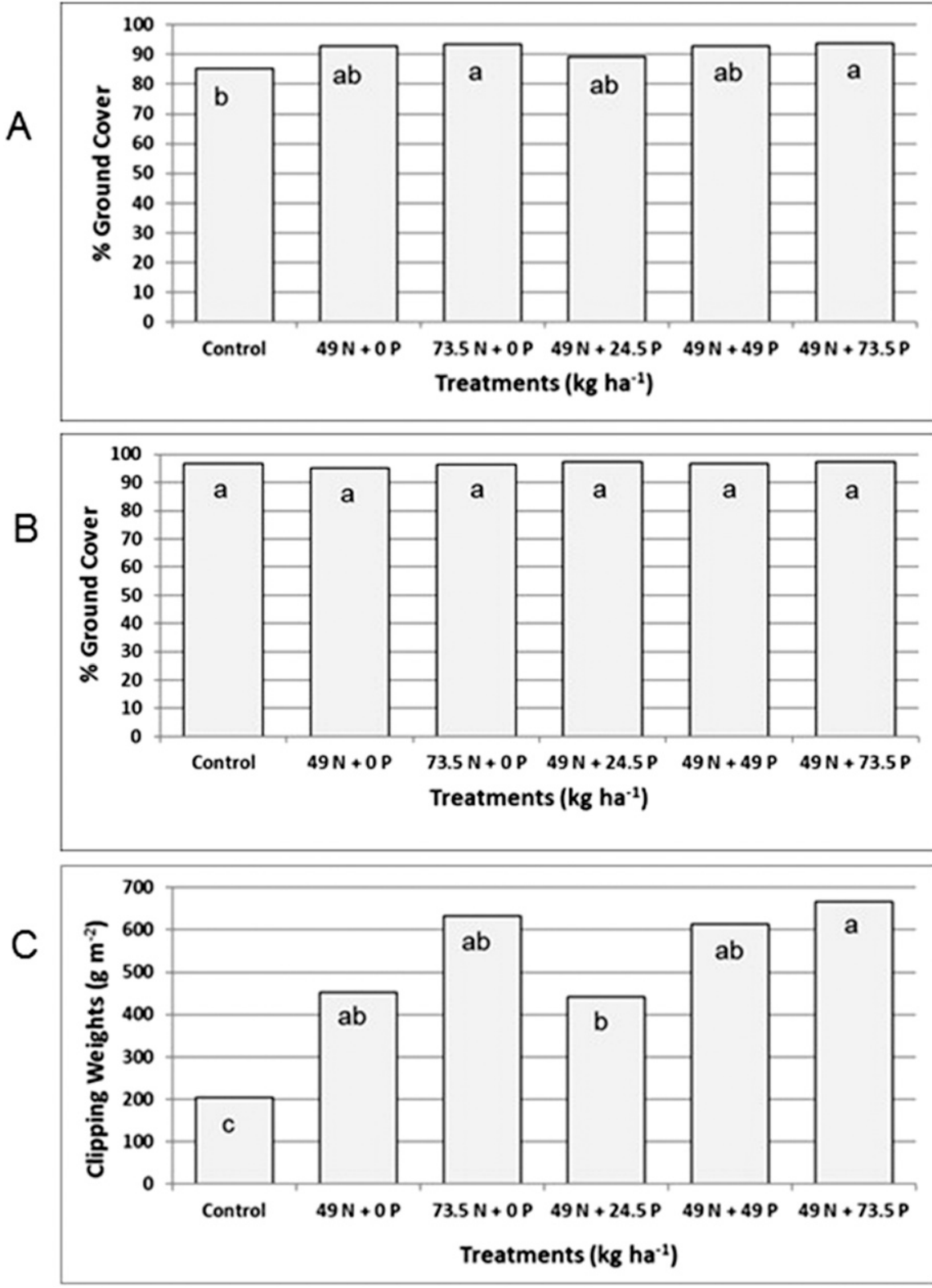

Fig. 3. Percentage of turf groundcover assessed visually on 27 Sept. (A), percentage of groundcover assessed digitally on 20 Nov. (B), and combined clipping weights (C) from the 2012 tilled soil N and P fertilizer experiment at the Landscape Management Research Center in University Park, PA.

experiment. Soil samples to a depth of $7.6 \mathrm{~cm}$ were collected from individual plots at the conclusion of the 2011 and 2012 JVTRC core-aerated and sliced soil experiments on 8 Nov. 2011 and on 10 Nov. 2012.

Data analysis procedures for experiments on tilled and core-aerated and sliced soil. All data from the tilled and core-aerated and sliced soil experiments were subjected to analysis of variance (ANOVA) using PROC GLM and ANOVA using SAS STAT Software (version 9.3; SAS Institute, Inc., Cary, NC). Fisher's protected least significant difference test was used to separate treatment means at $P \leq 0.05$. Additionally, treatments using $49 \mathrm{~kg} \cdot \mathrm{ha}^{-1} \mathrm{~N}$ with $\mathrm{P}$ and $49 \mathrm{~kg} \cdot \mathrm{ha}^{-1} \mathrm{~N}$ without $\mathrm{P}$ were compared and contrasted to determine groundcover, yield, Mehlich-3 P, and tissue $\mathrm{N}$ and $\mathrm{P}$. A regression analysis was groundcover. Regression analysis indicated no linear or quadratic groundcover effects for treatments at any time during the 2011 experiment.

The ANOVA of 2011 groundcover data from all tilled soil treatments showed differences between the control and all other treatments on both evaluation dates, indicating that fertilizer treatments had a positive influence on groundcover (Fig. 2A and B). There was less groundcover with the $49 \mathrm{~kg} \cdot \mathrm{ha}^{-1} \mathrm{~N}$ treatment when compared with all other fertilizer treatments on the 22 Oct. rating date, but no differences were detected among any of the other fertilizer treatments. No groundcover differences were found among any fertilizer treatments at the conclusion of the experiment on 4 Nov., and none of the treatments produced $>90 \%$ groundcover during the 2011 experiment.

Comparisons of the 2012 visual and digital groundcover data revealed no differences between the $49 \mathrm{~kg} \cdot \mathrm{ha}^{-1} \mathrm{~N}$ treatment and 49 $\mathrm{kg} \cdot \mathrm{ha}^{-1} \mathrm{~N}+\mathrm{P}$ treatments on any evaluation date (Table 1). Additionally, no linear or quadratic groundcover effects were detected for treatments during the 2012 experiment.

The ANOVA of 2012 groundcover data from all tilled soil treatments showed a lower percentage of groundcover with the control compared with the $73.5 \mathrm{~kg} \cdot \mathrm{ha}^{-1} \mathrm{~N}$ and 49 $\mathrm{kg} \cdot \mathrm{ha}^{-1} \mathrm{~N}+73.5 \mathrm{~kg} \cdot \mathrm{ha}^{-1} \mathrm{P}$ treatments on 27 Sept., $33 \mathrm{~d}$ after seeding (Fig. 3A). Most of the fertilizer treatments produced $>90 \%$ groundcover at $33 \mathrm{~d}$ after seeding. No groundcover differences were detected among any of the treatments at the conclusion of the 2012 experiment on 20 Nov. (Fig. 3B). All treatments, including the nonfertilized control, produced $>90 \%$ groundcover by 20 Nov.

Comparisons between the $49 \mathrm{~kg} \cdot \mathrm{ha}^{-1} \mathrm{~N}$ and $49 \mathrm{~kg} \cdot \mathrm{ha}^{-1} \mathrm{~N}+\mathrm{P}$ treatments on tilled soil showed no yield differences or positive linear or quadratic relationships regarding the clipping yields in 2011 and 2012 (Table 3). Clipping yields were much greater and more variable during the 2012 experiment than during the 2011 experiment, and three harvests were needed to remove rapidly developing leaf growth. This may have been due to a significant amount of $\mathrm{N}$ released from thatch tilled into the soil just before seeding was performed for the 2012 experiment.

The ANOVA of the tilled soil experiment clipping yield data for all treatments showed lower clipping yields for the nonfertilized control compared with the fertilizer treatments in 2011 and in 2012. In 2011, the $49 \mathrm{~kg} \cdot \mathrm{ha}^{-1} \mathrm{~N}$ and the $49 \mathrm{~kg} \cdot \mathrm{ha}^{-1} \mathrm{~N}+49 \mathrm{~kg} \cdot \mathrm{ha}^{-1} \mathrm{P}$ treatments produced lower clipping yields than did the 73.5 $\mathrm{kg} \cdot \mathrm{ha}^{-1} \mathrm{~N}$ treatment (Fig. 2C). In 2012, the 49 $\mathrm{kg} \cdot \mathrm{ha}^{-1} \mathrm{~N}+24.5 \mathrm{~kg} \cdot \mathrm{ha}^{-1} \mathrm{P}$ treatment produced lower clipping yields compared with the 49 $\mathrm{kg} \cdot \mathrm{ha}^{-1} \mathrm{~N}+73.5 \mathrm{~kg} \cdot \mathrm{ha}^{-1} \mathrm{P}$ treatment; no differences occurred among any of the other fertilizer treatments (Fig. 3C).

Mehlich-3 P and leaf tissue $\mathrm{N}$ and $\mathrm{P}$ data were compared for the 2011 and 2012 tilled soil experiments using $49 \mathrm{~kg} \cdot \mathrm{ha}^{-1} \mathrm{~N}$ and 49 $\mathrm{kg} \cdot \mathrm{ha}^{-1} \mathrm{~N}+\mathrm{P}$ treatments (Table 4). Higher Mehlich-3 P levels for the $49 \mathrm{~kg} \cdot \mathrm{ha}^{-1} \mathrm{~N}+\mathrm{P}$ 
Table 2. Means of visual and digital estimates of tall fescue groundcover for treatments with $49 \mathrm{~kg} \cdot \mathrm{ha}^{-1} \mathrm{~N}$ during 2011 and 2012 following seeding on Hagerstown silt loam soil that was core-aerated and sliced. Plots were seeded on 9 Sept. for the 2011 experiment and on 14 Sept. for the 2012 experiment. Tests were conducted at the Joseph Valentine Research Center in University Park, PA.

\begin{tabular}{|c|c|c|c|c|c|c|}
\hline \multirow[b]{3}{*}{ Treatment $\left(\mathrm{kg} \cdot \mathrm{ha}^{-1}\right)$} & \multicolumn{3}{|c|}{2011 Expt. on aerated and sliced soil } & \multicolumn{3}{|c|}{2012 Expt. on aerated and sliced soil } \\
\hline & Visual groundcover & Visual groundcover & Digital groundcover & Visual groundcover & Visual groundcover & Digital groundcover \\
\hline & 10 Oct. $(\%)$ & 3 Nov. $(\%)$ & 3 Nov. $(\%)$ & 18 Oct. (\%) & 5 Nov. $(\%)$ & 5 Nov. $(\%)$ \\
\hline $49 \mathrm{~N}+0 \mathrm{P}$ & 43 & 89 & 95 & 53 & 93 & 99 \\
\hline $49 \mathrm{~N}+24.5 \mathrm{P}$ & 45 & 92 & 94 & 60 & 97 & 99 \\
\hline $49 N+49 P$ & 40 & 93 & 94 & 53 & 95 & 99 \\
\hline $49 \mathrm{~N}+73.5 \mathrm{P}$ & 41 & 90 & 93 & 53 & 94 & 98 \\
\hline \multicolumn{7}{|c|}{ Significance probability } \\
\hline Contrast $^{z}$ & $0.44^{\mathrm{NS}}$ & $0.32^{\mathrm{NS}}$ & $0.06^{\mathrm{NS}}$ & $0.52^{\mathrm{NS}}$ & $0.18^{\mathrm{NS}}$ & $0.85^{\mathrm{NS}}$ \\
\hline Linear & $0.14^{\mathrm{NS}}$ & $0.68^{\mathrm{NS}}$ & $0.35^{\mathrm{NS}}$ & $0.64^{\mathrm{NS}}$ & $0.91^{\mathrm{NS}}$ & $0.39^{\mathrm{NS}}$ \\
\hline Quadratic & $0.15^{\mathrm{NS}}$ & $0.24^{\mathrm{NS}}$ & $0.06^{\mathrm{NS}}$ & $0.53^{\mathrm{NS}}$ & $0.13^{\mathrm{NS}}$ & $0.18^{\mathrm{NS}}$ \\
\hline \multicolumn{7}{|c|}{ Linear coefficient of determination } \\
\hline$R^{2}$ & 0.20 & 0.02 & 0.09 & 0.02 & 0.001 & 0.08 \\
\hline
\end{tabular}

${ }^{\mathrm{z}}$ Comparisons between treatment with $\mathrm{N}$ but no $\mathrm{P}$ and treatments with $\mathrm{N}$ and $\mathrm{P}$ were used for trend analyses.

NS Nonsignificant at $P \leq 0.05$.
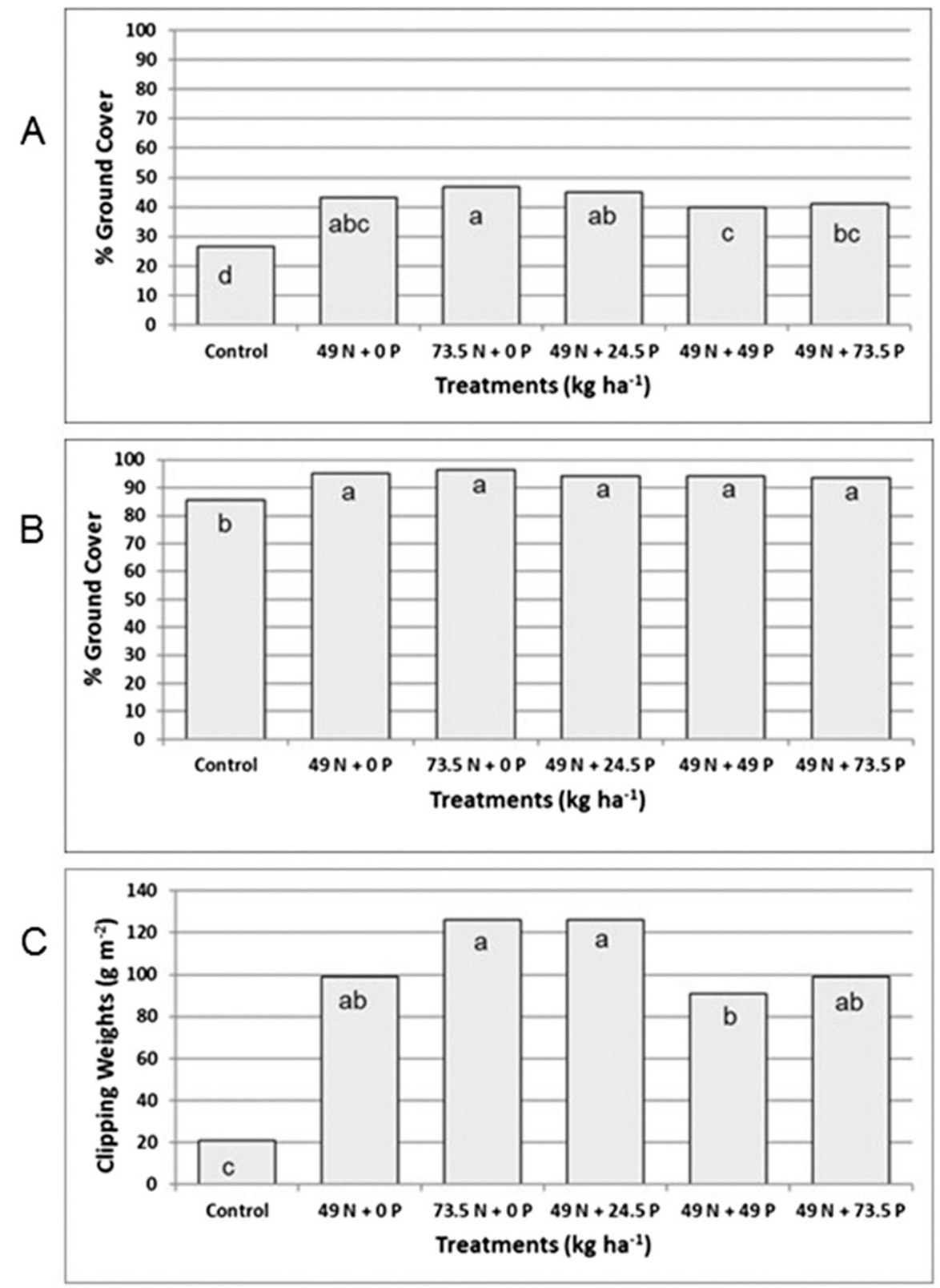

Fig. 4. Percentage of turf groundcover assessed visually on 10 Oct. (A), percentage of groundcover assessed digitally on 3 Nov. (B), and clipping weights on 3 Nov. (C) from the 2011 core-aerated and sliced soil $\mathrm{N}$ and $\mathrm{P}$ fertilizer experiment at the Joseph Valentine Turfgrass Research Center in University Park, PA. treatments compared with those for the $49 \mathrm{~kg} \cdot \mathrm{ha}^{-1} \mathrm{~N}$ treatment were found at the end of the 2011 and 2012 experiments. Positive linear and quadratic relationships were detected between Mehlich-3 P levels and $\mathrm{P}$ fertilizer application rates of both experiments. Mehlich-3 $\mathrm{P}$ was lower with the $49 \mathrm{~kg} \cdot \mathrm{ha}^{-1} \mathrm{~N}$ and $49 \mathrm{~kg} \cdot \mathrm{ha}^{-1} \mathrm{~N}+24.5$ $\mathrm{kg} \cdot \mathrm{ha}^{-1} \mathrm{P}$ treatments at the end of the 2012 experiment than it was with the initial pretreatment level of $53 \mathrm{mg} \cdot \mathrm{kg}^{-1}$. This may have been due to the uptake and removal of some $P$ contained in the large amounts of clippings harvested during the 2012 experiment.

Comparisons between the $49 \mathrm{~kg} \cdot \mathrm{ha}^{-1} \mathrm{~N}$ and $49 \mathrm{~kg} \cdot \mathrm{ha}^{-1} \mathrm{~N}+\mathrm{P}$ treatments showed no tissue $\mathrm{N}$ differences or linear or quadratic relationships regarding tissue $\mathrm{N}$ in 2011 and 2012 (Table 4). However, the tissue $\mathrm{N}$ levels for all treatments were higher during the 2012 experiment than during the 2011 experiment.

For tissue $\mathrm{P}$, comparisons of the 49 $\mathrm{kg} \cdot \mathrm{ha}^{-1} \mathrm{~N}$ and $49 \mathrm{~kg} \cdot \mathrm{ha}^{-1} \mathrm{~N}+\mathrm{P}$ treatments showed no differences between the 2011 and 2012 experiments (Table 4). A regression analysis revealed a positive linear relationship for tissue $\mathrm{P}$ and the $\mathrm{P}$ rate in 2011; however, actual differences in tissue $\mathrm{P}$ between treatments were small $\left(\leq 0.5 \mathrm{~g} \cdot \mathrm{kg}^{-1}\right)$. No linear or quadratic relationships were observed in 2012 (Table 4).

Fertilizer $N$ and $P$ experiments on coreaerated and sliced soil. Comparisons between the $49 \mathrm{~kg} \cdot \mathrm{ha}^{-1} \mathrm{~N}$ treatment and $49 \mathrm{~kg} \cdot \mathrm{ha}^{-1} \mathrm{~N}+\mathrm{P}$ treatments in 2011 and 2012 indicated no differences in groundcover for any of the six visual or digital evaluations. No positive linear or quadratic effects were detected for groundcover during 2011 and 2012 (Table 2).

The ANOVA of 2011 groundcover data from all treatments revealed differences between the control and all other treatments on all evaluation dates, indicating that fertilizer treatments had a positive influence on groundcover. On the 10 Oct. rating date, more groundcover was found for the $73.5 \mathrm{~kg} \cdot \mathrm{ha}^{-1} \mathrm{~N}$ treatment than for the $49 \mathrm{~kg} \cdot \mathrm{ha}^{-1} \mathrm{~N}+49 \mathrm{~kg} \cdot \mathrm{ha}^{-1} \mathrm{P}$ and $49 \mathrm{~kg} \cdot \mathrm{ha}^{-1} \mathrm{~N}+73.5 \mathrm{~kg} \cdot \mathrm{ha}^{-1} \mathrm{P}$ treatments (Fig. 4A). However, no differences in groundcover were found among any of the fertilizer treatments at the conclusion of the experiment on 
A

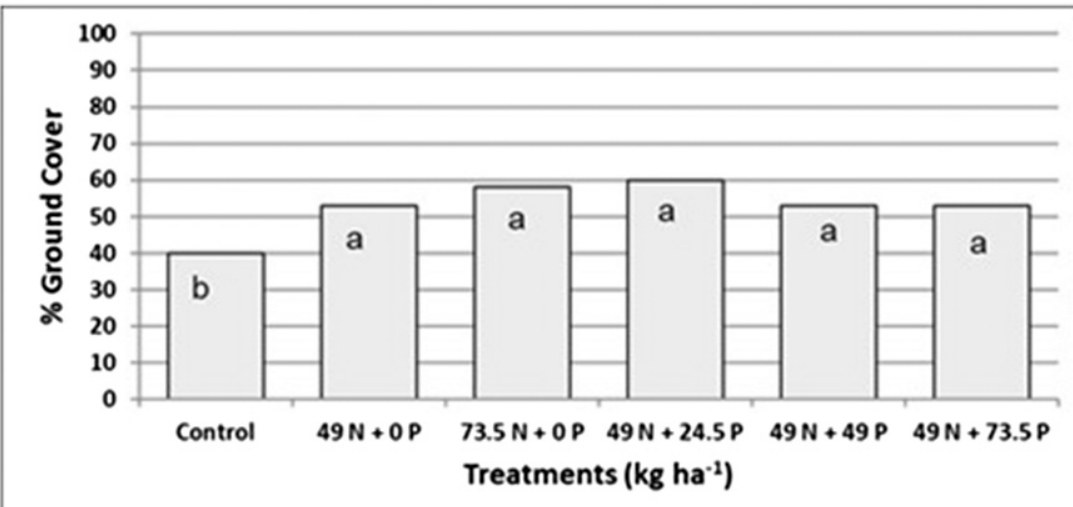

B
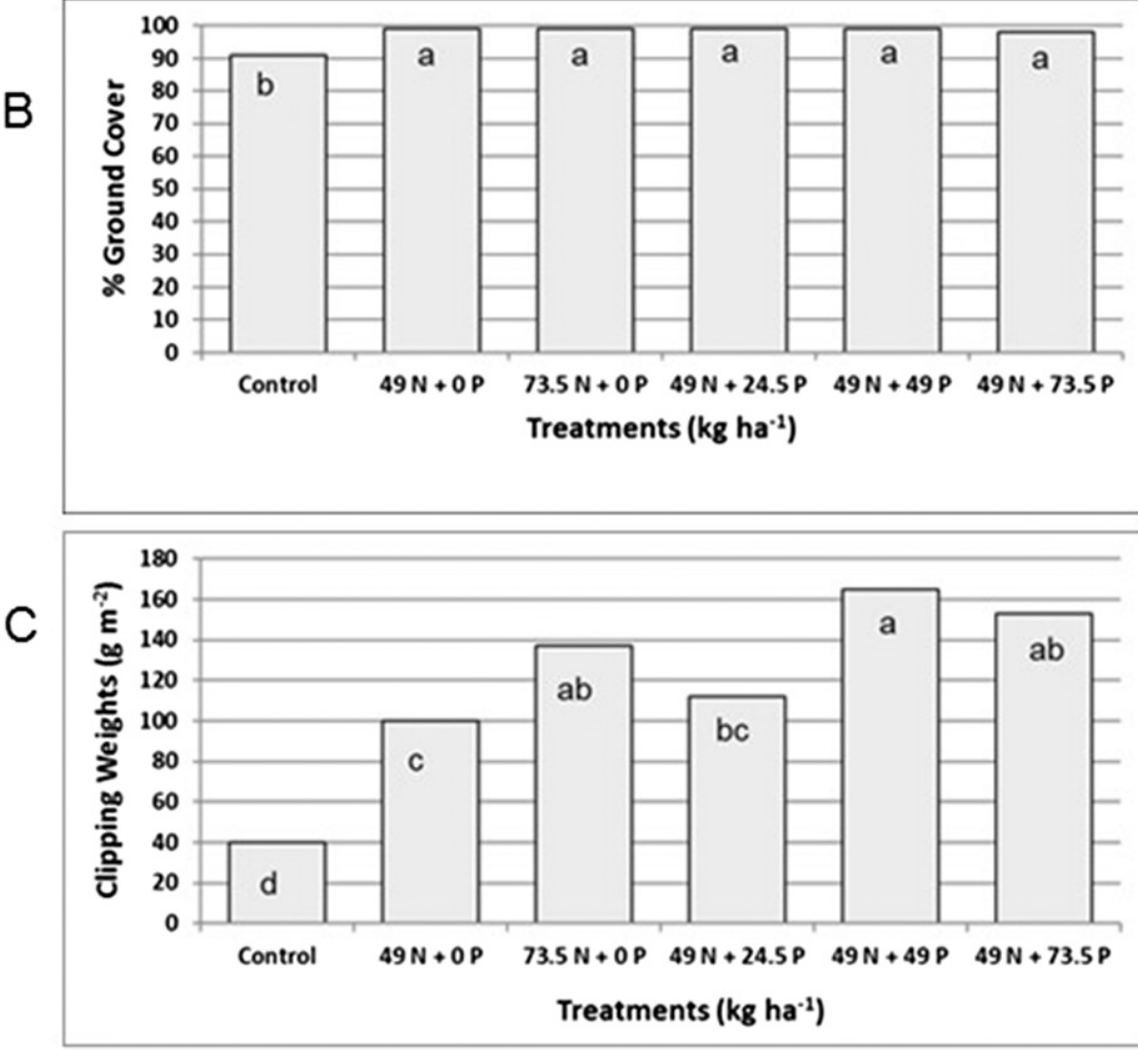

Fig. 5. Percentage of turf groundcover assessed visually on 18 Oct. (A), percentage of groundcover assessed digitally on 5 Nov. (B), and clipping weights on 5 Nov. (C) from the 2012 core-aerated and sliced soil $\mathrm{N}$ and $\mathrm{P}$ fertilizer experiment at the Joseph Valentine Turfgrass Research Center in University Park, PA.

3 Nov. (Fig. 4B). According to digital estimates, all fertilizer treatments produced $>90 \%$ groundcover at the end of the 2011 experiment.

The ANOVA of the 2012 core-aerated and sliced soil experiment groundcover data revealed differences between the control and all other treatments on all evaluation dates (Fig. 5A and B). No differences in groundcover were detected among any of the fertilizer treatments on the 18 Oct. rating date or 5 Nov. 2012 rating date. At the conclusion of the 2012 core-aerated and sliced soil experiment, all fertilizer treatments produced $>90 \%$ turf cover.

Comparisons of the $49 \mathrm{~kg} \cdot \mathrm{ha}^{-1} \mathrm{~N}$ and 49 $\mathrm{kg} \cdot \mathrm{ha}^{-1} \mathrm{~N}+\mathrm{P}$ treatments showed no clipping yield differences or positive linear or quadratic relationships for the clipping yield in 2011 (Table 3). In 2012, comparisons showed a clipping yield response to $P$ additions, as well experiments according to treatment (Table 5). Comparisons indicated no differences in Mehlich-3 P levels between the $49 \mathrm{~kg} \cdot \mathrm{ha}^{-1} \mathrm{~N}$ treatment and the $49 \mathrm{~kg} \cdot \mathrm{ha}^{-1} \mathrm{~N}+\mathrm{P}$ treatments at the conclusion of the 2011 experiment. This was the only experiment in which increases in Mehlich-3 P were not detected; therefore, it may reflect a higher degree of variability in $\mathrm{P}$ at this site. In the 2012 experiment, comparisons indicated an increase in Mehlich-3 P in response to $\mathrm{P}$ additions. Furthermore, positive linear and quadratic relationships were detected between Mehlich-3 P soil test levels and P fertilizer application rates in 2012.

Comparisons between the $49 \mathrm{~kg} \cdot \mathrm{ha}^{-1} \mathrm{~N}$ and $49 \mathrm{~kg} \cdot \mathrm{ha}^{-1} \mathrm{~N}+\mathrm{P}$ treatments showed no tissue $\mathrm{N}$ differences or linear or quadratic relationships regarding tissue $\mathrm{N}$ in 2011 and 2012 (Table 5). Tissue $\mathrm{N}$ for all treatments was considerably higher in the 2012 experiment than in the 2011 experiment, possibly reflecting inherently higher soil $\mathrm{N}$ at the 2012 site when the experiment was initiated.

For tissue $\mathrm{P}$, comparisons between the 49 $\mathrm{kg} \cdot \mathrm{ha}^{-1} \mathrm{~N}$ and $49 \mathrm{~kg} \cdot \mathrm{ha}^{-1} \mathrm{~N}+\mathrm{P}$ treatments showed no differences in the 2011 experiment and no linear or quadratic relationships regarding tissue P (Table 5). In 2012, differences were significant, and the regression analysis revealed a positive linear relationship regarding tissue $\mathrm{P}$ and the $P$ rate. Tissue $P$ ranged from $4.8 \mathrm{~g} \cdot \mathrm{kg}^{-1}$ for the $49 \mathrm{~kg} \cdot \mathrm{ha}^{-1} \mathrm{~N}$ treatment to a high of $6.8 \mathrm{~g} \cdot \mathrm{kg}^{-1}$ for the $49 \mathrm{~kg} \cdot \mathrm{ha}^{-1} \mathrm{~N}+49 \mathrm{~kg} \cdot \mathrm{ha}^{-1} \mathrm{P}$ treatment in 2012. The $49 \mathrm{~kg} \cdot \mathrm{ha}^{-1} \mathrm{~N}+49 \mathrm{~kg} \cdot \mathrm{ha}^{-1} \mathrm{P}$ treatment also resulted in the highest clipping weight of all treatments, and it was the only treatment that produced a significantly higher clipping yield than that of the $49 \mathrm{~kg} \cdot \mathrm{ha}^{-1} \mathrm{~N}+24.5 \mathrm{~kg} \cdot \mathrm{ha}^{-1} \mathrm{P}$ treatment.

\section{Discussion}

The main objective of this study was to determine if $\mathrm{P}$ rates typically used in starter fertilizer applications at the time of seeding during late summer influence groundcover and foliar growth of newly established tall fescue. Groundcover and growth measurements were important parameters used to assess turfgrass establishment because extensive turf cover can stabilize soil and reduce surface nutrient runoff from new establishments (Hamel and Heckman, 2006; Reicher et al., 2000). P-containing starter fertilizers are also used for improving root development of newly established grasses; however, measuring root growth was not an objective of this study.

Results from four experiments revealed few significant groundcover responses to the addition of $\mathrm{P}$ at rates of $24.5 \mathrm{~kg} \cdot \mathrm{ha}^{-1} \mathrm{P}, 49$ $\mathrm{kg} \cdot \mathrm{ha}^{-1} \mathrm{P}$, and $73.5 \mathrm{~kg} \cdot \mathrm{ha}^{-1} \mathrm{P}$. Of 12 groundcover assessments during the four experiments, comparisons revealed only one instance of a higher percentage of groundcover in response to the addition of $\mathrm{P}$. In this case, $\mathrm{P}$ treatments increased groundcover $12 \%$ to $17 \%$ at $34 \mathrm{~d}$ after seeding on tilled soil that had an initial Mehlich-3 P level of $38 \mathrm{mg} \cdot \mathrm{kg}^{-1}$. Previous research indicated that $38 \mathrm{mg} \cdot \mathrm{kg}^{-1}$ of Mehlich-3 P is not optimum for 
Table 3. Means of fresh clipping yields for treatments containing $49 \mathrm{~kg} \cdot \mathrm{ha}^{-1} \mathrm{~N}$ during 2011 and 2012 following seeding tall fescue on Hagerstown silt loam soil. Plots were seeded on 18 Sept. 2011 and 25 Aug. 2012 for the tilled soil experiments and on 9 Sept. 2011 and 14 Sept. 2012 for the core-aerated and sliced soil experiments. Tests were conducted at the Landscape Management Research Center (tilled soil experiments) and Joseph Valentine Research Center (aerated and sliced soil experiments) in University Park, PA.

\begin{tabular}{|c|c|c|c|c|}
\hline & 2011 tilled soil & 2012 tilled soil & 2011 aerated and sliced soil & 2012 aerated and sliced soil \\
\hline & $\overline{\text { Clipping yields }}$ & $\overline{\text { Combined clipping yields }^{z}}$ & Clipping yields & Clipping yields \\
\hline Treatment $\left(\mathrm{kg} \cdot \mathrm{ha}^{-1}\right)$ & $\overline{4 \text { Nov. }\left(\mathrm{g} \cdot \mathrm{m}^{-2}\right)}$ & $\left(\mathrm{g} \cdot \mathrm{m}^{-2}\right)$ & 3 Nov. $\left(\mathrm{g} \cdot \mathrm{m}^{-2}\right)$ & 5 Nov. $\left(\mathrm{g} \cdot \mathrm{m}^{-2}\right)$ \\
\hline$\overline{49 N+0 P}$ & 35 & 452 & 99 & 100 \\
\hline $49 \mathrm{~N}+24.5 \mathrm{P}$ & 45 & 441 & 126 & 112 \\
\hline $49 \mathrm{~N}+49 \mathrm{P}$ & 34 & 613 & 91 & 165 \\
\hline $49 \mathrm{~N}+73.5 \mathrm{P}$ & 40 & 666 & 99 & 153 \\
\hline \multicolumn{5}{|c|}{ Significance probability } \\
\hline Contrast $^{\mathrm{y}}$ & $0.41^{\mathrm{NS}}$ & $0.51^{\mathrm{NS}}$ & $0.63^{\mathrm{NS}}$ & $0.04 *$ \\
\hline Linear & $0.91 \mathrm{NS}$ & $0.13^{\mathrm{NS}}$ & $0.53^{\mathrm{NS}}$ & $0.01 * *$ \\
\hline Quadratic & $0.99^{\mathrm{NS}}$ & $0.29^{\mathrm{NS}}$ & $0.79^{\mathrm{NS}}$ & $0.04 *$ \\
\hline \multicolumn{5}{|c|}{ Linear coefficient of determination } \\
\hline$R^{2}$ & 0.001 & 0.21 & 0.04 & 0.47 \\
\hline
\end{tabular}

${ }_{\mathrm{z}}$ Total combined clippings harvested on 24 Sept., 11 Oct., and 20 Nov. 2012.

${ }^{\mathrm{y}}$ Comparisons between treatment with $\mathrm{N}$ but no $\mathrm{P}$ and treatments with $\mathrm{N}$ with $\mathrm{P}$ were used for trend analyses.

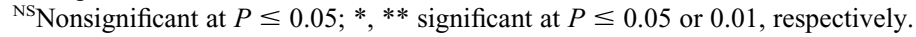

Table 4. Means of Mehlich-3 P, tissue N, and tissue P for treatments containing $49 \mathrm{~kg} \cdot \mathrm{ha}^{-1} \mathrm{~N}$ in 2011 and 2012 following seeding tall fescue on tilled Hagerstown silt loam soil. Plots were seeded on 18 Sept. in the 2011 experiment and on 25 Aug. in the 2012 experiment. Tests were conducted at the Landscape Management Research Center in University Park, PA.

\begin{tabular}{|c|c|c|c|c|c|c|}
\hline \multirow{2}{*}{ Treatment $\left(\mathrm{kg} \cdot \mathrm{ha}^{-1}\right)$} & \multicolumn{3}{|c|}{2011 Expt. on tilled soil } & \multicolumn{3}{|c|}{2012 Expt. on tilled soil } \\
\hline & Mehlich-3 P & Tissue $\mathrm{N}$ & Tissue $\mathrm{P}$ & Mehlich-3 P & Tissue $\mathrm{N}^{\mathrm{z}}$ & Tissue $\mathrm{P}$ \\
\hline $49 \mathrm{~N}+0 \mathrm{P}$ & 42 & 39 & 3.2 & 42 & 46 & 3.7 \\
\hline $49 \mathrm{~N}+49 \mathrm{P}$ & 62 & 38 & 3.3 & 59 & 46 & 4.1 \\
\hline $49 \mathrm{~N}+73.5 \mathrm{P}$ & 78 & 38 & 3.5 & 78 & 46 & 4.0 \\
\hline \multicolumn{7}{|c|}{ Significance probability } \\
\hline Contrast $^{\mathrm{y}}$ & $0.009 * *$ & $0.22^{\mathrm{NS}}$ & $0.42^{\mathrm{NS}}$ & $<0.01 * *$ & $0.90 \mathrm{NS}$ & $0.31^{\mathrm{NS}}$ \\
\hline Quadratic & $0.007 * *$ & $1.00^{\mathrm{NS}}$ & $0.15^{\mathrm{NS}}$ & $0.003 * *$ & $0.85^{\mathrm{NS}}$ & $0.37^{\mathrm{NS}}$ \\
\hline \multicolumn{7}{|c|}{ Linear coefficient of determination } \\
\hline$R^{2}$ & 0.67 & 0.004 & 0.34 & 0.70 & 0.02 & 0.19 \\
\hline
\end{tabular}

${ }^{\mathrm{z}}$ Tissue $\mathrm{N}$ and $\mathrm{P}$ obtained from weighted subsamples from clippings harvested on 24 Sept., 11 Oct., and 20 Nov. 2012.

${ }^{\mathrm{y}}$ Comparisons between treatment with $\mathrm{N}$ but no $\mathrm{P}$ and treatments with $\mathrm{N}$ with $\mathrm{P}$ were used for trend analyses.

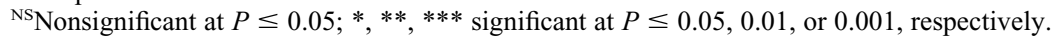

Table 5. Means of Mehlich-3 P, tissue N, and tissue P for treatments with $49 \mathrm{~kg} \cdot \mathrm{ha}^{-1} \mathrm{~N}$ in 2011 and 2012 following seeding tall fescue on Hagerstown silt loam soil that was core-aerated and sliced. Plots were seeded on 9 Sept. in the 2011 experiment and on 14 Sept. in the 2012 experiment. Tests were conducted at the Joseph Valentine Research Center in University Park, PA.

\begin{tabular}{|c|c|c|c|c|c|c|}
\hline \multirow{2}{*}{ Treatment $\left(\mathrm{kg} \cdot \mathrm{ha}^{-1}\right)$} & \multicolumn{3}{|c|}{2011 Expt. on aerated and sliced soil } & \multicolumn{3}{|c|}{2012 Expt. on aerated and sliced soil } \\
\hline & Mehlich-3 P & Tissue $\mathrm{N}$ & Tissue $\mathrm{P}$ & Mehlich-3 P & Tissue $\mathrm{N}$ & Tissue $\mathrm{P}$ \\
\hline $49 \mathrm{~N}+0 \mathrm{P}$ & 241 & 38 & 4.8 & 78 & 53 & 4.8 \\
\hline $49 \mathrm{~N}+49 \mathrm{P}$ & 290 & 38 & 5.0 & 106 & 54 & 6.8 \\
\hline $49 \mathrm{~N}+73.5 \mathrm{P}$ & 277 & 39 & 5.1 & 105 & 53 & 6.4 \\
\hline \multicolumn{7}{|c|}{ Significance probability } \\
\hline Contrast $^{2}$ & $0.18^{\mathrm{NS}}$ & $0.60^{\mathrm{NS}}$ & $0.06^{\mathrm{NS}}$ & $0.05^{*}$ & $0.76^{\mathrm{NS}}$ & $<0.001 * * *$ \\
\hline \multicolumn{7}{|c|}{ Linear coefficient of determination } \\
\hline$R^{2}$ & 0.28 & 0.10 & 0.18 & 0.50 & 0.02 & 0.62 \\
\hline
\end{tabular}

${ }^{\mathrm{z}}$ Comparisons between treatment with $\mathrm{N}$ but no $\mathrm{P}$ and treatments with $\mathrm{N}$ and $\mathrm{P}$ were used for trend analyses.

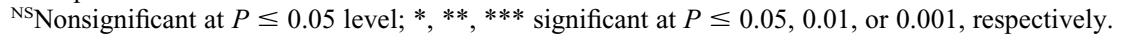

rapid establishment of cool-season turfgrasses (Carroll et al., 2005; Hamel and Heckman, 2006; Turner and Waddington, 1983).

At the end of the 2011 tilled soil experiment, no increases in groundcover or clipping yield due to the addition of $\mathrm{P}$ were detected; however, $\mathrm{P}$ fertilizer treatments increased soil Mehlich-3 P from $58 \mathrm{mg} \cdot \mathrm{kg}^{-1}$ with the $49 \mathrm{~kg} \cdot \mathrm{ha}^{-1} \mathrm{~N}+24.5 \mathrm{~kg} \cdot \mathrm{ha}^{-1} \mathrm{P}$ treatment to $78 \mathrm{mg} \cdot \mathrm{kg}^{-1}$ with the $49 \mathrm{~kg} \cdot \mathrm{ha}^{-1} \mathrm{~N}+73.5$ $\mathrm{kg} \cdot \mathrm{ha}^{-1} \mathrm{P}$ treatment. Possible reasons for the lack of a significant groundcover response to $P$ at the end of the experiment could have been that tall fescue was not able to sustain rapid growth and $\mathrm{P}$ uptake due to colder temperatures in late October, or that much of the $\mathrm{P}$ fertilizer was no longer in the vicinity of the expanding root tissues. Clipping yields as well as $\mathrm{N}$ and $\mathrm{P}$ tissue levels at the end of the 2011 tilled soil experiment were among the lowest of the four experiments, possibly due to the later planting date (18 Sept.), cold temperatures in October, and inherently low soil N. Studies performed in different plant culture systems have demonstrated reduced $\mathrm{P}$ uptake under cold temperatures and lower $P$ recovery in situations in which plant growth is limited by low or inadequate $\mathrm{N}$ (Kussow et al., 2012; Marschner, 1995; Selles et al., 2011). 
No groundcover or yield differences were observed between the $49 \mathrm{~kg} \cdot \mathrm{ha}^{-1} \mathrm{~N}$ and 49 $\mathrm{kg} \cdot \mathrm{ha}^{-1} \mathrm{~N}+\mathrm{P}$ treatments at any time during the 2012 tilled soil experiment, even though the initial Mehlich-3 P level of $53 \mathrm{mg} \cdot \mathrm{kg}^{-1}$ was below the critical growth response value of $280 \mathrm{mg} \cdot \mathrm{kg}^{-1}$ for tall fescue, as reported by Hamel and Heckman (2006) for New Jersey soils, and the $97 \mathrm{mg} \cdot \mathrm{kg}^{-1}$ Mehlich-3 P level above which no $\mathrm{P}$ response was observed for tall fescue in Maryland soils (Carroll et al., 2005). One possible explanation for the lack of a groundcover or yield response to the addition of $\mathrm{P}$ is that significant amounts of $\mathrm{N}$ released from $2.5 \mathrm{~cm}$ of thatch that was tilled into the soil diluted the groundcover and growth responses resulting from uptake and assimilation of $\mathrm{P}$. Warm soil temperatures resulting from the early planting date of 25 Aug. may have facilitated rapid breakdown of thatch and accelerated the growth of seedlings. Groundcover was $>90 \%$ at $33 \mathrm{~d}$ after seeding for most fertilizer treatments, and prolific foliar growth required three separate harvests, which amounted to the highest clipping weights of any of the four experiments and leaf tissue $\mathrm{N}$ up to $4.6 \mathrm{~g} \cdot \mathrm{kg}^{-1}$. Studies using ${ }^{15} \mathrm{~N}$-labeled fertilizer have shown that thatch can retain significant amounts of $\mathrm{N}$ for long periods in living turf stands (Miltner et al., 1996; Starr and DeRoo, 1981).

Results of the 2011 and 2012 core-aerated and sliced soil experiments revealed no differences in groundcover resulting from the $49 \mathrm{~kg} \cdot \mathrm{ha}^{-1} \mathrm{~N}$ and $49 \mathrm{~kg} \cdot \mathrm{ha}^{-1} \mathrm{~N}+\mathrm{P}$ treatments. Furthermore, there was no clipping yield response from $P$ treatments in the 2011 experiment. These results were not surprising because the initial Mehlich-3 $\mathrm{P}$ level at the 2011 site was $270 \mathrm{mg} \cdot \mathrm{kg}^{-1}$. This value is close to the critical Mehlich-3 $\mathrm{P}$ value of $280 \mathrm{mg} \cdot \mathrm{kg}^{-1}$ for tall fescue establishment proposed by Hamel and Heckman (2006). Clipping weights and tissue $\mathrm{N}$ levels were lower during the 2011 core-aerated and sliced soil experiment than during the 2012 core-aerated and sliced soil experiment, perhaps due to a low amount of $\mathrm{N}$ in the soil.

The 2012 core-aerated and sliced soil experiment with an initial Mehlich-3 P level of $66 \mathrm{~kg} \cdot \mathrm{ha}^{-1}$ was the only experiment in which comparisons indicated greater clipping yields resulting from $\mathrm{P}$ treatments when compared with the same amount of $\mathrm{N}$ fertilizer with no $\mathrm{P}$. The reason why $\mathrm{P}$ additions produced a clipping yield response in this experiment and not in others is not clear, but it could be due to compacted soil restricting the root development to the surface of the soil, where P from starter applications tends to accumulate. Soil samples taken on $3 \mathrm{Dec}$. 2012 at two different depths that were treated with $49 \mathrm{~kg} \cdot \mathrm{ha}^{-1} \mathrm{~N}+73.5 \mathrm{~kg} \cdot \mathrm{ha}^{-1} \mathrm{P}$ showed an average of $143 \mathrm{~kg} \cdot \mathrm{ha}^{-1}$ Mehlich-3 $\mathrm{P}$ at the surface and at the $0-$ to $5.1-\mathrm{cm}$ depth and an average of $80 \mathrm{~kg} \cdot \mathrm{ha}^{-1}$ Mehlich-3 P at the 5.1to $10.2-\mathrm{cm}$ depth. The clipping yield response to $\mathrm{P}$ appeared to be related to $\mathrm{P}$ uptake, as indicated by higher tissue $\mathrm{P}$ levels with increasing $\mathrm{P}$ rates $\left(R^{2}=0.62\right)$. Tissue $\mathrm{P}$ ranged from 5.7 to $6.8 \mathrm{~g} \cdot \mathrm{kg}^{-1}$ for $\mathrm{P}$ treatments, which was the highest tissue $\mathrm{P}$ of any treatment during the four experiments. This was the only experiment in which tissue $\mathrm{P}$ increased with increasing rates of $P$.

Although tall fescue groundcover and yield responses to $\mathrm{P}$ in starter fertilizer were somewhat variable in this study, the 73.5 $\mathrm{kg} \cdot \mathrm{ha}^{-1} \mathrm{~N}$ treatment with no $\mathrm{P}$ consistently showed similar or higher groundcover and yields than all other treatments. These results indicated that increasing $\mathrm{N}$ rates by 24.5 $\mathrm{kg} \cdot \mathrm{ha}^{-1}$ during late summer establishments may help turf managers achieve relatively fast groundcover when P-containing starter fertilizers are not available, or if $\mathrm{P}$ is banned in environmentally sensitive areas.

\section{Conclusions}

The results of this study showed few significant tall fescue groundcover responses and variable clipping yield responses to the addition of $\mathrm{P}$ at rates used for starter fertilizer applications to silt loam soil during late summer and fall. Although the range of soil test P levels was limited in these experiments, the findings indicate that groundcover and growth responses due to $\mathrm{P}$ in starter fertilizers do not appear to be solely related to soil test $\mathrm{P}$ levels, and other factors such as the method of establishment (tilling with a rototiller vs. core-aerating and vertical slicing of the soil), environmental conditions, and perhaps the $\mathrm{N}$ content of soil may be involved.

Factors that may have influenced $P$ availability and uptake in this study include the use of ammonium-N fertilizer, an endophytecontaining tall fescue cultivar (Bullseye), and the effects of tillage on mycorrhizal colonization of roots. Ammonium-N sources, such as ammonium sulfate and MAP, typically enhance $\mathrm{P}$ availability and uptake relative to nitrate-N sources due to acidification of the rhizosphere (Hinsinger, 2001; Gahoonia et al., 1992; Riley and Barber, 1971). Certain tall fescue ecotypes infected with Neotyphodium coenophialum (Morgan-Jones and Gams, Glenn, Bacon, and Hanlin) accumulate higher concentrations of $\mathrm{P}$ and produce greater shoot dry weights than nonendophyte ecotypes in low-P soils (Rahman, 2007). Although mycorrhizal colonization of developing turfgrass root systems in recently tilled soil is not thoroughly understood, studies of other cropping systems have demonstrated higher vesicular-arbuscular mycorrhizal root colonization and $\mathrm{P}$ absorption in young shoot tissues of corn (Zea mays L.) planted with no-till techniques compared with corn planted in soil tilled with a moldboard plow (Galvez et al., 2001; McGonigle and Miller, 1993).

The experiments in this study were conducted under near-optimum conditions for turfgrass establishment; therefore, the results may not be indicative of tall fescue growth responses to $\mathrm{P}$ in starter fertilizer in different soils and under adverse conditions. Under adverse conditions (cold temperatures, limited moisture, or soils with high sand or clay contents), P-containing starter fertilizers are more likely to confer an advantage in the rate of establishment (Barber, 1984; Carroll et al., 2005). When $P$ cannot be used for new establishments, increasing $\mathrm{N}$ rates may be an alternative to using $\mathrm{P}$-containing starter fertilizers if soil test $P$ levels are $\geq 38 \mathrm{mg} \cdot \mathrm{kg}^{-1}$ Mehlich-3 P.

\section{Literature Cited}

Agricultural Analytical Services Lab (AASL). 2017. Soil fertility testing recommendation handbooks: Soil test recommendations for turf, 2101 home lawn to plant. $<$ http://agsci. psu.edu/aasl/soil-testing/soil-fertility-testing/ handbooks/turf/recommendations/2101-home-lawnto-plant>.

Barber, S.A. 1984. Soil nutrient bioavailability. John Wiley and Sons, New York, NY.

Carroll, M.J., T.Q. Ngo, and J.M. Krouse. 2005. Tall fescue seedling growth in response to phosphorus fertilization. Intl. Turfgrass Soc. Res. J. 10:310-317.

Christians, N.E., D.P. Martin, and K.J. Karnock. 1981. The interaction among nitrogen, phosphorus, and potassium on the establishment, quality, and growth of Kentucky bluegrass (Poa pratensis L. 'Merion'), p. 341-348. In: R.W. Sheard (ed.). Proc $4^{\text {th }}$ Intl. Turfgrass Res. Conf., Guelph, Ont., Canada.

Gahoonia, T.S., N. Claassen, and A. Jungk. 1992. Mobilization of phosphate in different soils by ryegrass supplied with ammonium or nitrate. Plant Soil 140:241-248.

Galvez, L., D.D. Douds, L.E. Drinkwater, and P. Wagoner. 2001. Effect of tillage and farming system upon VAM fungus populations and mycorrhizas and nutrient uptake of maize. Plant Soil 228:299-308.

Hamel, S.C. and J.R. Heckman. 2006. Predicting need for phosphorus fertilizer by soil testing during seeding of cool season grasses. HortScience 41:1690-1697.

Hardebeck, G., C. Bigelow, K. Walker, and D.R. Smith. 2005. Impact of pre-plant phosphorus and potassium on turf type tall fescue establishment. In: Proceedings of the ASA-CSSASSSA Annual Meeting Abstracts, Nov. 6-10, 2005, Salt Lake City, UT. 2005 CDROM; < https://crops. confex.com/crops/2005am/techprogram/P8419. HTM>.

Hinsinger, P. 2001. Bioavailability of soil inorganic $\mathrm{P}$ in the rhizosphere as affected by rootinduced chemical changes: A review. Plant Soil 237:173-195.

Horneck, D.A. and R.O. Miller. 1998. Determination of total nitrogen in plant tissue. In: Y.P. Kalra (ed.). Handbook and reference methods for plant analysis. CRC Press, New York, NY.

Huang, C.L. and E.E. Schulte. 1985. Digestion of plant tissue for analysis by ICP emission spectroscopy. Commun. Soil Sci. Plant Anal. 16:943958.

Karcher, D.E. and M.D. Richardson. 2005. Batch analysis of digital images to evaluate turfgrass characteristics. Crop Sci. 45:1536-1539.

Kussow, W.R., D.S. Soldat, W.C. Kreuser, and S.M. Houlihan. 2012. Evidence, regulation, and consequences of nitrogen-driven nutrient demand by turfgrass. ISRN Agronomy 2012, Article ID 359284, 9 pages. doi: 105402/2012/ 359284.

Marschner, H. 1995. Mineral nutrition of higher plants. 2nd ed. Academic Press Inc., San Diego, CA

McGonigle, T.P. and M.H. Miller. 1993. Mycorrhizal development and phosphorus absorption in maize under conventional and reduced tillage. Soil Sci. Soc. Amer. J. 57:1002-1006. 
Mehlich, A. 1984. Mehlich 3 soil test extractant: A modification of Mehlich 2 extractant. Commun. Soil Sci. Plant Anal. 15:1409-1416.

Milesi, C., S. Running, C. Elvidge, J. Deitz, B. Tuttle, and R. Nemani. 2005. Mapping and modeling the biogeochemical cycling of turf grasses in the United States. Environ. Mgt. 36:426-438.

Miltner, E.D., B.E. Branham, E.A. Paul, and P.E. Rieke. 1996. Leaching and mass balance of ${ }^{15}$ N-labeled urea applied to a Kentucky bluegrass turf. Crop Sci. 36:1427-1433.

Rahman, M.H. 2007. Endophyte effects on nutrient acquisition in tall fescue grown in Andisols. $\mathrm{J}$. Plant Nutr. 30:2141-2158.

Reicher, Z.J., C.S. Throssell, and D.V. Weisenberger. 2000. Date of seeding affects establishment of coolseason turfgrasses. HortScience 35:1166-1169.

Riley, D. and S.A. Barber. 1971. Effect of ammonium and nitrate fertilization on phosphorus uptake as related to root-induced $\mathrm{pH}$ changes at the root-soil interface. Soil Sci. Soc. Amer. Proc. 35:301-306.
Roth, G.W., D.B. Beegle, S.M. Heinbaugh, and M.E. Antle. 2006. Starter fertilizers for corn on soils testing high in phosphorus in the Northeastern USA. Agron. J. 98:1121-1127.

Schueler, T. 2010. The clipping point: Turf cover estimates for the Chesapeake Bay watershed and management implications. Chesapeake Stormwater Network Technical Bulletin \#8. $<$ http://chesapeakestormwater.net/2012/03/ technical-bulletin-no-8-the-clipping-point/>.

Selles, F., C.A. Campbell, R.P. Zentner, D. Curtin, D.C. James, and P. Basnyat. 2011. Phosphorus use efficiency and long-term trends in soil available phosphorus in wheat production systems with and without nitrogen fertilizer. Can J. Soil Sci. 91:39-52.

Soldat, D.J. and A.M. Petrovic. 2008. The fate and transport of phosphorus in turfgrass ecosystems. Crop Sci. 48:2051-2065.

Starr, J.L. and H.C. DeRoo. 1981. The fate of nitrogen fertilizer applied to turfgrass. Crop Sci. 21:531-536.
Turner, T.R. and D.V. Waddington. 1983. Soil test calibrations for establishment of turfgrass monostands. Soil Sci. Soc. Amer. J. 47:11611166.

Vetsch, J.A. and G.W. Randall. 2000. Enhancing no-tillage systems for corn with starter fertilizers, row cleaners, and nitrogen placement methods. Agron. J. 92:309-315.

Wolf, A.M. and D.B. Beegle. 1995. Recommended soil tests for macronutrients: Phosphorus, potassium, calcium, and magnesium, p. 25-34. In: J.T. Sims and A. Wolf (eds.). Recommended soil testing procedures for the Northeastern United States. Northeast regional bulletin \#493. Agricultural Experiment Station, University of Delaware, Newark, DE.

USEPA. 2010. Chesapeake Bay TMDL Executive Summary, 14 pp. <http://www.epa.gov/ reg3wapd/pdf/pdf_chesbay/FinalBayTMDL/ BayTMDLExecutiveSummaryFINAL122910 final.pdf $>$. 